\title{
UPAYA MENINGKATKAN PROFESIONALITAS GURU MELALUI PENDAMPINGAN PENULISAN PROPOSAL PENELITIAN TINDAKAN KELAS (PTK)
}

\author{
Mela Darmayanti ${ }^{1}$, Non Dwishiera Cahya Anasta ${ }^{2}$, Arie Rakmat Riyadi ${ }^{3}$ Effy Mulyasari $^{4}$ \\ 1,2, 3,4 Universitas Pendidikan Indonesia
}

\begin{abstract}
Classroom Action Research (CAR) is a report of the teacher's real activities in solving problems that occur in teaching and learning activities in the classroom while improving the quality of learning in accordance with the teacher's professional development goals. In fact, UPI PGSD Primary School teachers still encounter difficulties in making PTK proposals as an initial step in fulfilling their professional competencies. Based on this, this study aims to improve the competency of SD PGSD UPI Partner teachers in preparing PTK proposals. The form of activities carried out is assistance with the deductive training model. This research is a quantitative research in the form of a descriptive approach. Data collection was obtained through a questionnaire distributed to 18 PGSD UPI Partner school teachers as mentoring participants. The study began with an identification of the needs of UPI PGSD Primary School SD teachers, followed by assistance in the preparation of the CAR proposal. Assistance materials include CAR in the development of the teaching profession, CAR credit report figures, exploring research problems, and preparing CAR proposals. The results showed an increase in the ability of understanding teachers in preparing PTK proposals.
\end{abstract}

Keyword: Assistance, Classroom Action Research Proposal, Teacher Professionalism

\begin{abstract}
Abstrak: Penelitian Tindakan Kelas (PTK) merupakan laporan kegiatan nyata guru dalam menyelesaikan masalah yang terjadi dalam kegiatan belajar-mengajar di kelas sekaligus memperbaiki mutu pembelajaran sesuai dengan tujuan pengembangan profesi guru. Pada kenyataannya guru SD Mitra PGSD UPI masih menemui kesulitan dalam membuat proposal PTK sebagai langkah awal pemenuhan kompetensi profesinya. Berdasarkan hal tersebut penelitian ini bertujuan untuk meningkatkan kompetensi guru SD Mitra PGSD UPI dalam menyusun proposal PTK. Bentuk kegiatan yang dilakukan yaitu pendampingan dengan model pelatihan deduktif. Penelitian ini merupakan penelitian kuantitatif dalam bentuk pendekatan deskriptif. Pengumpulan data didapatkan melalui angket yang disebar pada 18 guru sekolah Mitra PGSD UPI selaku peserta pendampingan. Penelitian diawali dengan identifikasi kebutuhan guru SD Mitra PGSD UPI, dilanjutkan dengan pendampingan penyusunan proposal PTK. Materi Pendampingan meliputi PTK dalam pengembangan profesi guru, angka kredit laporan PTK, penggalian masalah penelitian, dan penyusunan proposal PTK. Hasil penelitian menunjukan adanya peningkatan kemampuan pemahaman guru dalam menyusun proposal PTK.
\end{abstract}

Kata Kunci: Pendampingan, Proposal Penelitian Tindakan Kelas, Profesionalitas Guru

\footnotetext{
'Universitas Pendidikan Indonesia, Email: meladarmayanti国upi.edu

2Universitas Pendidikan Indonesia, Email: shiera.vh回gmail.com

${ }^{3}$ Universitas Pendidikan Indonesia, Email: arie.riyadi国upi.edu

${ }^{4}$ Universitas Pendidikan Indanesia, Email: effy国upi.edu
} 


\section{PENDAHULUAN}

Penelitian Tindakan Kelas (PTK) bukanlah sebuah istilah asing bagi seorang pendidik, khususnya guru di Sekolah Dasar. Kegiatan PTK terintegrasi dengan pelaksanaan proses pembelajaran di kelas, sehingga tidak akan mengganggu tugas guru untuk mengajar. Jenis penelitian ini merupakan yang termudah dan paling cocok bagi guru, karena dilakukan oleh guru di dalam kelasnya berdasarkan pada permasalahan yang dialami (Sanjaya, 2016). Di dalam kegiatan pembelajaran, guru secara langsung berinteraksi dengan siswa, sehingga guru akan betul-betul memahami permasalahan yang terjadi di dalam kegiatan pembelajarannya. Dengan demikian guru memiliki kewajiban untuk mencari solusi/ pemecahan masalah untuk setiap permasalahan yang terjadi di dalam kegiatan pembelajarannya.

Penyelesaian masalah yang terjadi di dalam kelas dalam hal ini terkait proses dan hasil pembelajaran, akan memberikan perbaikan pada kualitas pembelajaran. Salah satu upaya untuk meningkatkan kualitas proses dan hasil pembelajaran harus diawali dengan meningkatkan mutu guru sebagai tenaga pendidikan. Guru merupakan komponen pendidikan yang memiliki peran penting dalam kegiatan belajar mengajar. Jika tugas seorang guru hanyalah menyampaikan materi, tentu semua orang dapat melakukannya. Namun istilah guru merupakan sebuah profesi yang berdasarkan UU NO 14 Tahun 2005 merupakan pendidik profesional dengan tugas utama mendidik, mengajar, membimbing, mengarahkan, melatih, menilai, dan mengevaluasi peserta didik pada pendidikan anak usia dini jalur pendidikan formal, pendidikan dasar, dan pendidikan menengah.

Berdasarkan hal tersebut di dalam sebuah kegiatan belajar mengajar, seorang guru bukan hanya sebagai penyampai materi, namun juga harus mampu membimbing, mengarahkan, melatih,menilai dan mengevaluasi peserta didik. Hal ini dapat tercapai jika guru mampu merancang pembelajaran sesuai dengan kebutuhan dan tujuan pemeblajaran. Guru harus berperan sebagai perancang atau desainer pembelajaran agar dapat memenuhi tugas utamanya. Guru harus mampu mendesain proses pembelajaran secara produktif, efektif, efisien dan inovatif (Sani, 2013). Guru sebagai sebuah profesi juga harus mampu menjalankan tugasnya secara profesional (Jihad, 2013). Peningkatan profesionalisme guru berkaitan erat dengan penulisan karya tulis ilmiah. Melalui kegiatan penelitian ilmiah guru dapat meningkatkan profesionalitasnya sebagai guru serta dapat meningkatkan kualitas layanan pembelajaran juga pengelolaan kelas. PTK merupakan suatu bentuk kegiatan ilmiah yang dapat dilakukan guru di dalam kelas dengan melakukan berbagai tindakan untuk meningkatkan proses dan hasil pembelajaran.

Pada hakikatnya kegiatan ilmiah PTK berfungsi sebagai bahan refleksi diri, khususnya dalam proses belajar mengajar di kelas yang dapat dipertanggungjawabkan (Hopkins, 2011). Selain berdampak langsung pada kualitas pembelajaran, PTK juga menjadi sebuah syarat untuk kenaikan pangkat/golongan para guru. Di dalam UU memang tidak dinyatakan secara langsung bahwa guru memiliki kewajiban untuk melakukan penelitian, berbeda halnya dengan profesi dosen. Akan tetapi berdasarkan Permen PAN No 16 Tahun 2009 Pasal 11.c mengenai pengembangan keprofesian yang berkelanjutan, dinyatakan bahwa publikasi atas hasil penelitian menjadi salah satu hal yang wajib dipenuhi guru selama bertugas dalam profesinya. Selain itu dikuatkan pula oleh Peraturan bersama Mendiknas dan Kepala BAKN Nomor 03/V/PB/2010 dan Nomor 14 Tahun 2010 yang menyatakan bahwa syarat kenaikan pangkat/ jabatan guru dari III/b ke pangkat jabatan lebih tinggi yaitu dengan melaksanakan kegiatan pengembangan diri dan publikasi ilmiah yang antara lain yaitu 
hasil PTK. Dengan demikian kegiatan meneliti maupun menulis bagi guru mau tidak mau menjadi sebuah keharusan untuk dilaksanakan.

Sebelum melakukan penelitian, seorang guru perlu menyusun rencana penelitian dalam bentuk proposal PTK agar dapat melaksanakan kegiatan PTK dengan baik dan terencana (Subarman: 1994). Namun pada kenyataannya masih banyak guru yang merasa kesulitan untuk meyusun proposal PTK terlebih untuk melaksanakan kegiatan meneliti dan menulis laporan PTK. Berdasarkan hasil identifikasi masalah pada guru sekolah mitra PGSD UPI, banyak guru yang mengeluhkan adanya keharusan penelitian sebagai persyaratan untuk memperoleh pengakuan dan tunjangan atas profesinya, karena guru yang merasa kesulitan untuk membuat proposal PTK, terlebih untuk melaksanakan PTK serta membuat laporan hasil penelitiannya.

Banyak alasan yang mendasari kesulitan tersebut, seperti kurangnya pemahaman guru tentang penyusunan proposal PTK serta pelaksanaannya di kelas. Pada dasarnya hal ini disebabkan oleh faktor terbatasnya pengetahuan guru tentang langkah-langkah penyusunan proposal PTK baik yang menyangkut diagnosis dan penetapan masalah, prosedur pelaksanaan PTK, bahkan dalam menyusun latar belakang, menentukan rumusan masalah, tujuan dan manfaat peneitian, menyusun kerangka teori dan meyusun skenario pembelajaran berdasarkan variabel yang ditetapkan. Kurangnya kemampuan guru-guru tersebut dalam menyusun proposal PTK disebabkan oleh kurangnya wadah yang bisa me-refresh pengetahuan para guru tetang PTK, serta tidak adanya bimbingan untuk para guru dalam melaksanakan kegiatan PTK.

Katiadaan

pembimbing menyebabkan kurangnya motivasi dan rasa percaya diri guru dalam menyusun proposal PTK. Hal tersebut akan bermuara pada kemampuan guru dalam menulis karya tulis ilmiah. Hal ini menjadi permasalahan yang harus segera disikapi dan dicarikan solusinya. Berdasarkan permasalahan tersebut, penelitian ini diharapkan dapat memberikan solusi untuk meningkatkan profesionalitas guru dalam menyusun proposal PTK. Pendampingan Penulisan proposal PTK merupakan salah satu upaya dan langkah nyata PGSD UPI untuk membangkitkan produktifitas guru mitra dalam kegiatan ilmiah. Upaya meningkatkan kompetensi guru sekolah mitra dalam menyusun proposal PTK ini perlu dilakukan dengan memberikan pelatihan yang sesuai dengan kebutuhan, agar guru sekolah mitra dapat menghasilkan proposal PTK dengan baik.

Pendampingan penyusunan

proposal PTK dengan pelatihan model deduktif dianggap efektif digunakan untuk meningkatkan kompetensi guru sekolah mitra dalam menyusun proposal PTK. Model pelatihan deduktif mengidentifikasi kebutuhan secara umum dengan sasaran yang luas, selain itu kebutuhan pelatihan untuk peserta didasarkan pada peserta yang memiiki karakteristik yang sama, maka hasil identifikasinyapun duduga dibutuhkan untuk keseluruhan peserta pelatihan yang memiliki ciri-ciri yang sama (Kamil, 2012). Model ini dipilih karena peserta pelatihan memiliki karakteristik yang sama yaitu seorang guru SD yang memiliki latar belakang pendidikan yang sama serta merupakan guru sekolah mitra PGSD UPI. Disamping itu kebutuhan pelatihan dalam penelitian ini juga bersifat terduga, dalam artian bahwa peserta pelatihan dalam hal ini guru sekolah mitra memiliki jenis kebutuhan yang sama yaitu harus mampu menyusun proposal PTK sebagai salah satu upaya untuk meningkatkan profesionalitasnya sebagai guru serta sebagai salah satu syarat untuk pengajuan kenaikan golongan. Hasil penelitian ini diharapkan dapat memotivasi para guru dalam menyusun proposal PTK dan melaksanakan PTK, serta bagi sekolah untuk dapat meningkatkan kinerja sekolah melalui peningkatkan profesionalitas guru. 


\section{METODOLOGI PENELITIAN}

Penelitian ini termasuk kedalam penelitian kuantitatif dalam bentuk pendekatan deskriptif. Pengumpulan data didapatkan melalu angket kuesioner. Adapun subjek penelitian yang mengikuti pendampingan penulisan proposal PTK berjumlah 18 orang. Ke 18 orang responden dalam penelitian ini berprofesi sebagai guru sekolah dasar di Kota Bandung, dan merupakan guru di sekolah mitra PGSD UPI. Bidang keahlian yang menjadi subjek kebutuhan adalah kompetensi profesional khususnya penulisan proposal PTK. Subjek penelitian dilakukan secara purposive dengan mempertimbangkan bahwa subjek adalah guru SD yang berlatar belakang pendidikan dari lulusan guru sekolah dasar dan memiliki kebutuhan untuk mengembangkan profesionalitasnya sebagai guru, serta memiliki kepentingan untuk dapat memnuhi syarat pengajuan kenaikan pangkat/golongan.

Pemateri dalam pendampingan ini berjumlah 5 orang dosen yang memiliki kompetensi di bidang pendidikan dan kejuruan. Materi pendampingan meliputi pemahaman pentingnya PTK dalam pengembangan profesi guru, angka kredit laporan PTK, penggalian masalah penelitian, dan penyusunan proposal PTK. Diawal dan diakhir kegiatan peserta pendampingan diminta untuk mengisi kuisioner yang sudah disiapkan oleh peneliti. Angket pertama digunakan untuk mengukur kemampuan responden dalam penulisan PTK. Selanjutnya, angket ke 2 digunakan agar peneliti mendapatkan data tentang keberhasilan dari implementasi pendampingan. Lokasi penelitian dan pendampingan penulisan proposal PTK untuk menigkatkan profesionalitas guru sekolah mitra dilaksanakan di gedung Aula Fakultas Ilmu Pendidikan UPI. Melalui kegiatan tersebut, diharapkan pemahaman dan keterampilan guru sekolah mitra dalam menyusun proposal PTK untuk meningkatkan profesionalitasnya menjadi lebih meningkat. Adapun indikator keberhasilan dalam penelitian ini yaitu, meningkatknya pengetahuan dan keterampilan guru sekolah mitra dalam menulis proposal PTK.

\section{HASIL PENELITIAN DAN PEMBAHASAN}

$\begin{array}{cr}\text { Sebelum } & \text { dilakukan } \\ \text { pendampingan } & \text { penyusunan } \\ \text { proposal }\end{array}$ PTK, guru-guru menyatakan mengalami kesulitan dalam menyusun proposal PTK baik dari segi isi maupun dalam menyusun kalimat (kebahasaan/pengkalimatan). Kesulitan menyusun proposal PTK tersebut mencakup semua aspek, dimulai dari Bab I yang meliputi; merumuskan judul penelitian, latar belakang masalah, rumusan masalah, tujuan penelitian, dan manfaat hasil penelitian. Bab II meliputi; pemaparan kajian teoritis, kerangka berpikir, serta hipotesis tindakan. Selanjutnya metode penelitian yang tertuang dalam Bab III meliputi; pemaparan tentang jenis, lokasi, dan subyek penelitian (prosedur penelitian dari setiap siklus), sumber data, cara pengambilan data, instrumen, dan pengolahan data, serta indikator keberhasilan penelitian. Kesulitan tersebut disebabkan karena guru-guru belum percaya diri dan belum memiliki pemahaman yang jelas tentang PTK dan cara menyusun proposal PTK yang benar, sehingga para guru takut untuk memulai menyusun proposal PTK.

Melalui pendampingan penulisan proposal PTK, guru SD Mitra mulai mampu menyusun proposal PTK sesuai dengan rambu-rambu penyusunan proposal PTK yang baik dari segi isi ataupun kebahasaan/pengkalimatan. Pada awal pelaksanaan pendampingan, pakar dalam hal ini pendamping terlebih dahulu memberikan penjelasan mengenai pengembangan profesi guru melalui PTK serta angka kredit laporan hasil PTK. Selanjutnya dijelaskan pula konsep PTK dan cara menyusun proposal PTK secara 
partisipatif. Dalam proses pendampingan pakar tidak hanya memberikan ceramah tapi melibatkan guru-guru dengan cara tanya jawab, diskusi dan pemberian contoh-contoh yang aplikatif, seperti dalam penggalian masalah penelitian. Setiap guru ditanya menganai permasalahan-permasalahan yang diterjadi di dalam kelasnya, dan masalah apa yang ingin segera dicari solusinya. Berdasarkan permasalahan tersebut, guru didampingi oleh pendamping untuk merumuskan variable-variable yang akan digunakan untuk membuat judul. Selanjutnya dilanjutkan dengan kegiatan pendampingan penyusun proposal PTK, hingga proposal PTK yang disusun oleh guru tersebut selesai.

Selama proses penyusunan proposal PTK terjalin pula interaksi antar guru dan guru, maupun guru dengan pendamping, baik dalam bentuk diskusi, tanya jawab, pengarahan dan motivasi. Semua peserta pendampingan tampak antusias, serius dan aktif dalam mengikuti kegiatan pendampingan, hal ini dibuktikan dengan berhasilnya para guru dalam menyusun proposal PTK, walaupun masih ditemukan kekurangan atau kesalahan di bagian/aspek-aspek tertentu. Namun demikian, jika dibandingkan dengan kondisi awal sebelum dilakukan tindakan pendampingan, dimana guru masih merasa belum memahami dan merasa kesulitan dalam menyusun proposal PTK, ternyata setelah dilakukan tindakan pendampingan, menunjukan adanya peningkatan pemahaman dan keterampilan guru dalam menulis proposal PTK. Data tersebut dapat dibuktikan dengan hasil perhitungan angket yang dibagikan pada responden dalam hal ini guru mitra PGSD UPI selaku peserta pendampingan, pada saat sebelum dan setelah pendampingan dilakukan. Adapun kondisi awal dan hasil yang dicapai melalui kegiatan pendampingan penulisan proposal PTK untuk meningkatkan propesionalitas guru melalui metode deduktif bagi guru sekolah mitra PGSD UPI yaitu sebagai berikut :
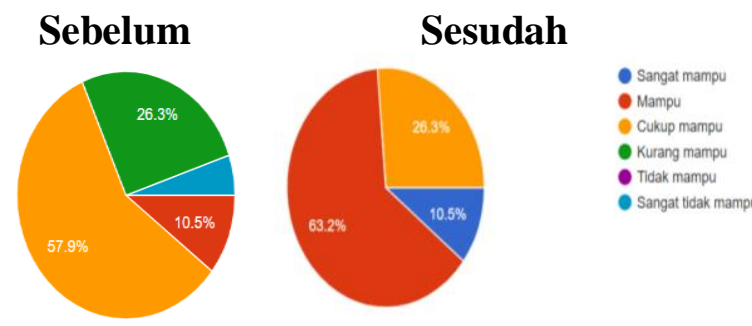

Gambar 1. Kompetensi Memahami Variabel PTK sebelum dan dan sesudah dilakukan pendampingan.

Sebelum dilakukan pendampingan, hanya $10,5 \%$ responden yang masuk kedalam kategori mampu merumuskan sebuah permasalahan ke dalam variable $\mathrm{x}$ dan y untuk dijadikan sebagai judul PTK. $57,9 \%$ guru masih merasa bingung dalam menentukan variable sehingga berada pada kategori cukup mampu, 26,3\% merasa kurang mampu, bahkan ditemui data adanya responden yang berada pada kategori sangat tidak mampu. Setelah dilakukan pendampingan, terlihat adanya peningkatan kemampuan guru dalam memahami variabel PTK, seperti adanya responden yang masuk kedalam kategori sangat mampu, selain itu terdapat kenaikan persentase jumlah responden mampu sebanyak $52,7 \%$ dan turunnya persentase jumlah responden yang berada pada kategori cukup mampu sebanyak $31,6 \%$. Selain itu juga, sudah tidak ditemukan responden yang berada dalam kategori sangat tidak mampu.

Kompetensi yang harus dimiliki guru dalam membuat proposal PTK selanjutnya Ialah membuat latar belakang. Berdasarkan hasil angket yang diisi responden didapatkan hasil sebagai berikut :

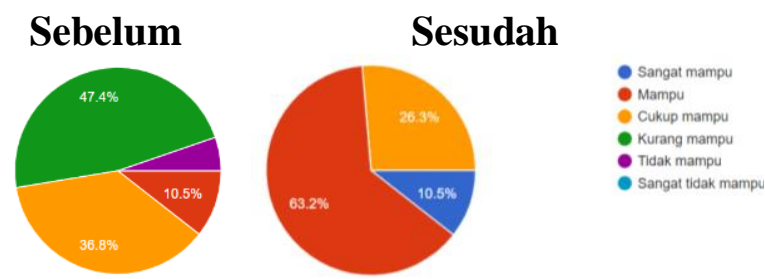

Gambar 2. Kompetensi Membuat Latar Belakang PTK sebelum dan sesudah dilakukan pendampingan 
Latar belakang merupakan kunci dalam sebuah proposal penelitian, namun sebelum dilakukan pendampingan ditemukan data bahwa kompetensi responden dalam membuat latar belakang belum memadai. Hanya $10,5 \%$ responden yang menyatakan mampu, sebanyak $47,4 \%$ responden berada pada kategori kurang mampu, 36,6\% merasa cukup mampu dan $11,3 \%$ merasa tidak mampu. Alasan utama yang mendasari hal ini, karena guru belum terbiasa menulis dan guru belum memahami sistematikan penulisan serta logika berpikir dalam menulis latar belakang. Setelah dilkakukan pendampingan terlihat adanya perubahan kemampuan guru dalam membuat latar belakang, terlihat dari adanya responden yang berada pada kategori sangat mampu, dan tidak adanya responden dalam kategori kurang mampu. Berdasarkan gambar diatas dapat dilihat adanya peningkatan presentase pemahaman guru dalam kategori mampu sebesar $52,7 \%$ dan penurunan kategori cukup mampu sebesar 11,5\%.

$$
\text { Kompetensi selanjutnya ialah }
$$

membuat rumusan masalah PTK. Berdasarkan hasil angket yang diisi responden didapatkan hasil sebagai berikut :
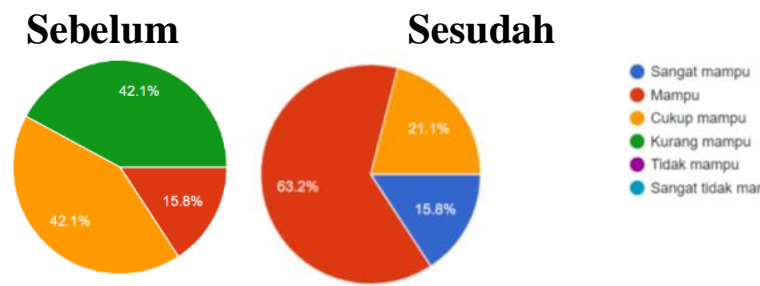

Gambar 3. Kompetensi Membuat rumusan masalah PTK sebelum dan sudah dilakukan Pendampingan

Dalam membuat rumusan masalah, sebanyak $42,1 \%$ responden yang berada dalam kategori kurang mampu menyatakan ketidakmampuan responden dalam menyatakan permasalahan dan tindakan yang diusulkan ke dalam sebuah kalimat yang singkat dan jelas. Adapun $42,1 \%$ responden yang berada pada kategori cukup mampu, menyatakan kebingungan dalam menentukan kalimat tanya yang sesuai, sedangkam $15,8 \%$ menyatakan mampu namun belum percaya diri akan kebenaran hasil tulisannya. Namun setelah dilakukan pendampingan, terdapat responden yang masuk dalam kategori sangat mampu, selain itu terjadi peningkatan persentase kemampuan responden dalam kategori mampu sebesar $47,4 \%$ dan penurunan persentase kategori cukup mampu sebanyak $21 \%$.

Selanjutnya ialah kompetensi membuat tujuan dan manfaat masalah penelitian dalam Proposal PTK. Berdasarkan hasil angket yang diisi responden didapatkan hasil sebagai berikut :

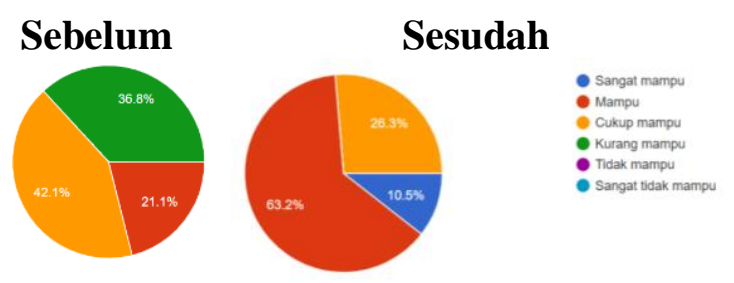

(Tujuan Penelitian)
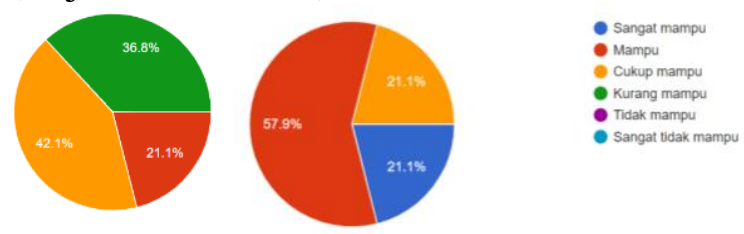

(Manfaat Penelitian)

Gambar 4. Kompetensi Membuat tujuan dan Manfaat masalah Penelitian sebelum dan sesudah dilakukan pendampingan

Gambar 4 menunjukan kompetensi responden dalam membuat tujuan dan manfaat penelitian. Berdasarkan hasil perhitungan didapatkan data $21,1 \%$ responden berada pada kategori mampu, $42,1 \%$ berada pada kategori cukup mampu dan $36,8 \%$ pada kategori kurang mampu. Data tersebut menunjukan masih perlunya bimbingan pada rumusan tujuan dan manfaat penelitian agar responden mencapai kategori mampu, sehingga dapat menghasilkan proposal PTK yang baik. Setelah dilakukan pendampingan, 
ditemukan data adanya peningkatan kemampuan guru dalam membuat tujuan dan manfaat penelitian seperti adanya responden dalam kategori sangat mampu, serta meningkatnya presentase responden dalam kategori mampu, dan terdapat penurunan persentase responden dalam kategori cukup mampu.

Kompetensi berikutnya yang harus dimiliki guru dalam membuar proposal PTK yaitu membuat tinjauan teoritik. Berdasarkan hasil perhitungan angket ditemukan data sebagai berikut.
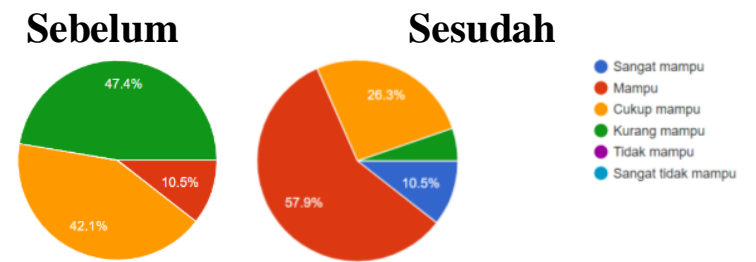

Gambar 6. Kompetensi Membuat Tinjauan Teoritik/ pustaka proposal PTK sebelum dan sesudsh dilakukan pendampingan

berdasarkan data, ditemui bahwa hanya $10,5 \%$ responden yang berada pada kategori mampu, sedangkan sebagian besar berada pada kategori kurang mampu sebanyak $47,4 \%$ dan $42,1 \%$ pada kategori cukup mampu. Dalam hal ini responden menyatakan tidak tahu teori -teori yang relevan untuk permasalahan yang dihadapi serta sulitnya menentukan penelitian yang dianggap memiliki relevansi dengan penelitian yang dilakukan. Namun setelah dilakukan pendampingan terjadi peningkatan kompetensi guru dalam membuat tinjauan teoritik. Dapat dilihat dari gambar 6 diatas yang menunjukan adanya responden dalam kategori sangat mampu, dan terjadi peningkatan persentase responden dalam kategori mampu sebesar $47,4 \%$ dan terjadi penurunan persentase responden dalam kategori cukup mampu sebesar 15,8\%.

Kompetensi akhir yang harus dikuasai oleh guru dalam membuat proposal PTK yaitu membuat susunan metode dan desain langkah-langkah PTK. Berdasarkan hasil perhitungan angket dihasilkan data sebagai berikut
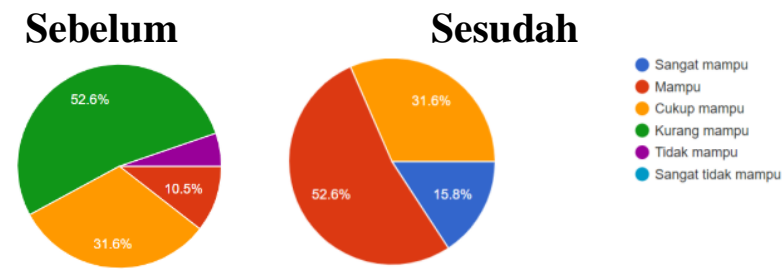

Gambar 7. Kompetensi Membuat Susunan Metode dan desain langkah-langkah PTK sebelum dan sesudah dilakukan pendampingan

Dalam kompetensi membuat susunan metode dan desain langkah-langkah PTK sebelum dilakukan pendampingan dihasilkan data $52,6 \%$ responden berada pada kategori kurang mampu, 31,6\% cukup mampu, $10,5 \%$ berada dalam kategori mampu. Namun masih terdapat responden yang berada pada kategori tidak mampu, sebanyak 5,3\%. Setelah dilakukan pendampingan terjadi peningkatkan kemampuan guru dalam membuat susunan metode dan desain langkah-langkah PTK. Hal ini dapat dilihat dari adanya responden yang masuk dalam kategri sangat mampu, dan terjadi peningkatan presentase responden dalam kategori mampu sebesar $42,1 \%$ serta tidak adanya responden dalam kategori tidak mampu.

Diagram-diagram

diatas menunjukan adanya peningkatan kompetensi guru dalam menyusun proposal PTK. Hal ini dapat dilihat dari adanya responden yang berada pada kategori sangat mampu, dari sebelumnya tidak ada, dan hilangnya responden dalam kategori kurang mampu dan tidak mampu. Peningkatan kompetensi tersebut menunjukan adanya peningkatan pemahaman responden terhadap materi yang disampaikan oleh para narasumber dan atau pendamping,

Setelah dilakukan pendampingan, responden diminta untuk memberikan tanggapannya terkait dengan kejelasan narasumber pelatihan serta kesan terhadap penyelenggaraan pendampingan. Data tersebut dijadikan dasar perbaikan untuk penyelenggaraan pendampingan sejenis di masa yang akan 
datang. Berdasarkan angket yang disebar kepada responden, menunjukkan bahwa kejelasan narasumber pendampingan PTK masuk dalam kategori sangat jelas, seperti tampak pada gambar diagram dibawah ini.

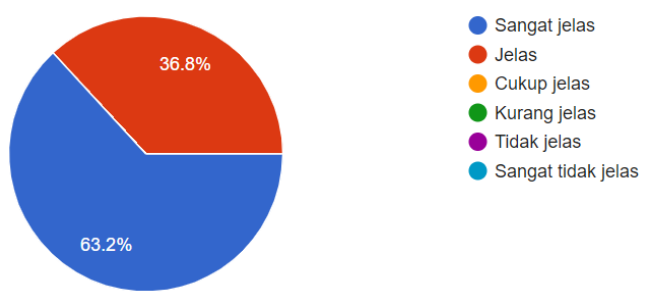

Gambar 8. Kesan Terhadap Penjelasan Narasumber Pendampingan PTK

Sebagian besar peserta pelatihan menyatakan bahwa penjelasan narasumber pada pendampingan PTK sangat jelas. Berdasarkan angket yang disebar kepada responden juga didapatkan data bahwa kesan peserta atas penyelenggaraan pendampingan ini masuk dalam kategori sangat memuaskan, seperti ditunjukkan pada Gambar 16 di bawah ini.
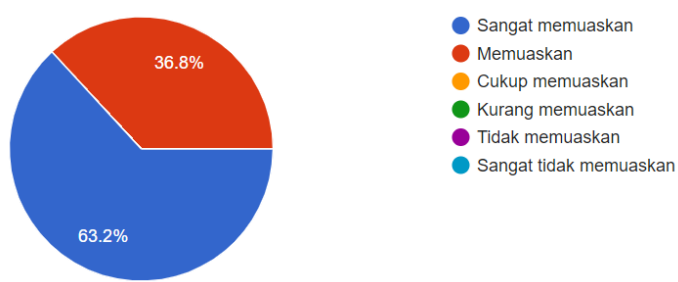

Gambar 9. Kesan Terhadap Penyelenggaraan Kegiatan

sebanyak $63,2 \%$ peserta memberikan kesan sangat memuaskan, dan $36,8 \%$ menyatakan memuaskan. Penilaian ini menjadi refleksi bagi tim peneliti, agar mampu menyelenggarakan pendampingan yang lebih baik lagi diwaktu yang akan datang.

Model pelatihan deduktif menurut Kamil (2012) yaitu model pelatihan yang identifikasi kebutuhan pelatihannya dilakukan secara umum dengan sasaran yang luas. Kebutuhan pelatihan ditetapkan atas dasar pengajuan pertimbangan dari semua peserta pelatihan yang memiliki karakteristik yang sama. ]Berdasarkan hal tersebut, identifikasi pendampingan dengan model pelatihan deduktif ini dilakukan secara umum dalam hal ini untuk memnuhi kebutuhan untuk meningkatkan profesionalitas guru, dengan sasaran yang luas yaitu guru-guru sekolah Mitra PGSD UPI. Identifikasi kebutuhan pada pendampingan ini didasarkan atas kebutuhan semua peserta pendampingan untuk meningkatan kompetensi profesionalitasnya sebagai guru dengan membuat proposal PTK. Hasil identifikasi ini diduga dibutuhkan untuk keseluruhan peserta pelatihan, karena semua peserta pelatihan memiliki ciri-ciri yang sama yaitu berlatar belakang sarjana pendidikan guru sekolah dasar, dan merupakan guruguru SD mitra PGSD UPI yang ingin membuat proposal PTK guna kenaikan golongannya. Identifikasi ini digunakan sebagai landasan dalam penyusunan materi pendampingan yang bersifat massal dan menyeluruh, yang kemudian dikembangkan pada proses pendampingan yang lebih khusus.

Penggunaan model pendampingan dengan model deduktif ini telah dapat mengatasi permasalahan guru-guru SD Mitra PGSD UPI dalam menyusun proposal PTK. Melalui pendampingan ini, minat, percaya diri serta kompetensi guruguru dalam menyusun proposal PTK menjadi semakin meningkat. Melalui pendampingan ini guru-guru merasa percaya diri dengan judul PTK-nya sehingga mampu menghasilkan proposal PTK yang akan diimplementasikan dalam penelitia di sekolahnya masing-masing. Peserta pendampingan dalam hal ini guruguru merespon positif pendampingan dengan model deduktif ini karena dapat memberikan bimbingan yang mereka butuhkan serta bermanfaat dalam membangun pengetahuan dan pemahaman mereka tentang konsep-konsep dalam penelitian tindakan kelas dan bagaimana menyusun proposal PTK. Hasil penelitian ini mendukung dan menambah temuan pada penelitian sebelumnya dari Mediatati (2016) yang menunjukan bahwa 
adanya peningkatan kemampuan guru dalam menyiapkan proposal PTK melalui implementasi model pelatihan partisipatif dengan pendampingan intensif selama 2 siklus, materi pelatihan dalam pelatihan ini didasari atas refleksi pada siklus 1 , dan dalam penelitian ini peserta terlibat aktif dari tahap awal persiapan pendampingan, hingga proses akhir pendampingan. Selanjutnya penelitian dari Pambudi (2018) dalam rangka meningkatkan profesionalisme guru melalui pelatihan PTK yang menunjukan adanya peningkatan kompetensi dan motivasi guru dalam membuat PTK melalui kegiatan pelatihan, sehingga PTK yang dihasilkan memenuhi standar dan layak diterbitkan.

\section{KESIMPULAN}

Dari hasil penelitian dan pembahasan yang telah dilakukan, diperoleh simpulan sebagai berikut: (1). Guruguru SD Mitra PGSD UPI mengalami kesulitan dalam menyusun proposal PTK baik dari aspek isi maupun pengkalimatan mulai dari menentukan variabel, perumusan latar belakang, rumusan masalah, tujuan penelitian, manfaat hasil penelitian, kajian teori/pustaka, kerangka berpikir, hipotesis tindakan dan metode penelitian, karena belum memiliki pemahaman yang jelas mengenai konsep PTK serta aplikasinya dalam penyusunan proposal PTK; (2). Penerapan model pelatihan partisipatif dengan pendampingan intensif dapat meningkatkan kompetensi menyusun proposal PTK dari guru-guru SD Mitra PGSD UPI, dilihat dari perubahan tingkat pemahaman guru-guru terhadap setiap aspek dalam penyusunan proposal PTK; dan (3). Meningkatnya motivasi guru-guru SD Mitra PGSD UPI dalam menyusun proposal PTK, karena bertambahnya pengetahua para guru terkait cara menulis karya ilmiah.

Berdasarkan simpulan tersebut dapat diberikan beberapa saran sebagai berikut :
1. Sebagai upaya tindak lanjut sebaiknya sekolah dalam hal ini kepala sekolah melakukan pengecekan kemajuan proposal PTK agar Proposal tersebut benar-benar diimplementasikan para guru di kelas agar dapat menghasilkan sebuah laporan penelitian tindakan kelas. Hal ini akan berdampak pada peningkatan kualitas pembelajaran dan profesionalitas guru di sekolah.

2. Bagi guru-guru peserta pendampingan, hendaknya proposal PTK yang telah disusun agar segera diimplementasikan dalam penelitian di kelasnya, sebagai salah satu pelaksanaan tugas profesinya. Penelitian yang telah dilakukan diharapkan dapat disusun menjadi sebuah laporannya dalam bentuk jurnal agar bermanfaat bagi peningkatan golongan atau jabatan fungsional guru. Selain itu, melalui pendampingan ini diharapkan guru menjadi terbiasa dalam menyusun proposal PTK.

\section{DAFTAR PUSTAKA}

Hopkins, D. (2011). Panduan Guru Penelitian Tindakan Kelas. Yogyakarta: Pustaka Pelajar.

Jihad. (2013). Menjadi Guru profesional : Strategi meningkatkan kualifikasi dan kualitas guru di era global. Jakarta : Erlangga.

Kamil, M. (2012). Model Pendidikan dan Pelatihan (Konsep dan Aplikasi). Bandung : Alfabeta.

Mediatati, N. (2016). "Upaya meningkatkan kompetensi guru dalam menyusun proposal Penelitian Tindakan Kelas Melalui Model Pelatihan Partisipatif dengan pendampingan Intensif". Jurnal Kelola. Vol 3 No.1 Hal 148163.

Pambudi, S. (2018). "Upaya Meningkatkan Profesionalisme Guru Melalui Pelatihan Peneltian Tindakan Kelas di SMK Muhammadiyah 1 Bantul". Jurnal Electronics, Informatics, and 
Vocational Education), November 2018; Vol 3 No.2. Hal 61-64.

Sani, R. A. (2013). "Inovasi Pembelajaran". Jakarta : Bumi Aksara.

Sanjaya, D. H. W (2016). Penelitian Tindakan Kelas. Prenada Media.

Subarman, E. (1994). Kemampuan Dasar Guru dalam Proses BelajarMengajar. Bandung : PT Remaja Rosdakarya.

Undang-Undang No. 14 Tahun 2005 tentang Guru dan Dosen. 